\title{
Stability of management of the organizations in the modern economic environment conditions
}

\author{
S.Yu. Ilyin ${ }^{1}$, O.N. Beketova ${ }^{2}$ I.N. Belousova ${ }^{2}, E . A$. Dudina $^{2}$, and S.N. Bukhantseva ${ }^{2}$ \\ ${ }^{1}$ Financial University under the Government of the Russian Federation, Leningradsky prospect, 51/1, \\ 125993, Russian Federation \\ ${ }^{2}$ MIREA - Russian technological university, Prospekt Vernadskogo, 78, 119454 Moscow, Russia
}

\begin{abstract}
The article contains the author's approach to the formation of indicators of sustainability of management of organizations. The developed approach holds the emphasis placed on its traditional understanding, transformed into the modern entrepreneurial era, based on the environment of the functioning of business processes of organizations' activities, composed of controlled (endogenous) and uncontrolled (exogenous) factors that form their management costs and determine total costs and efficiency, on which the financial benefit in the future period depends. The study considers selected resultant and factorial indicators of the sustainability of management of organizations: management efficiency and cost, changes in the dynamics of results and costs under the action of the specified qualitative and quantitative parameters of management activities. The basis for constructing dependencies between resulting and factorial indicators of the stability of management of organizations is the unity of differentiated by types of additive, multiplicative and multiple interactions, included in the selected combination of intermediate (factor) valueswith final (resulting) values. The integrity of all dependencies, forming a common system of the considered indicators will provide organizations with an accurate assessment of the analyzed final values and a gradation pursuant to the degree of value significancein the intermediate group and objective measures to optimize their management stability. The material may be beneficial for entrepreneurs operating under the current economic mechanism, regardless of spheres and industries, education and science specialists, students in management areas.
\end{abstract}

\section{Introduction}

The current stage of human development is characterized by an economic environment with a complex market mechanism with many factors of the current business environment, on which the capabilities and limitations of business entities in the production and output of products depend, without compliance with its requirements, they will not be able to be competitive in comparison with other representatives of the segment. First of all, it applies to organizations whose costs are much higher compared to individual entrepreneurs, who are more exposed to risks in terms of payback and profit in the amount required for expanded reproduction, which largely determines the resistance to the current economic situation, being a business environment. acting directly and indirectly on the results of activities. Adhering 
to this postulate, we will study indicators of the sustainability of management of organizations under the current circumstances of doing business, since the role of management is to find reserves for optimizing business processes.

The study is aimed to develop methods for calculating indicators that provide an objective assessment of the stability of the management of organizations to the economic environment (the environment for the functioning of business processes) in the modern nature of market relations to obtain information on the ranking of the influence of each factor indicator on it. It can be achieved by solving a number of study objectives:

1. Disclosure of the environment for the functioning of business processes of organizations in modern conditions of doing business.

2. Compilation of a list of groups of management costs, focusing on the functioning of organization business processes.

3. Comparison of the economic result with cost groups brought together into a single nomenclature, forming a system of interconnection of the resulting and factorial indicators of the stability of the management of organizations included in it, pursuant to the environment of their business processes.

We will solve the formulated tasks on the topic under study using the most suitable scientific materials and methods and techniques.

\section{Materials and methods}

The information sources were the works of researchers on the issues of managerial stability of organizations in the current environment for the functioning of their business processes. These include V. Andreev [1], N.S. Antonova [2], A.S. Belanovsky [3], S.N. Efimushkin [4], A.M. Zhemchugov [5], M.A. Kovtun [6], I. Kurnysheva [7], K.V. Pavlov [8], V.A. Rogov [9], R.O. Suleymanov [10], B.N. Khosiev [11], whose ideas contain prerequisites for the formation of indicators of stability of management of organizations to the conditions of the modern economic environment.

The research being carried out is based on the computational-constructive method, which combines in the process of forming methods an additive, multiplicative and multiple combination of dependencies between the resulting and factor indicators of the sustainability of the management of organizations. This approach is required for the complexity and consistency of the analysis of changes in results and costs, being the basic measure for assessing the managerial stability of organizations (the success of their business processes), with elements of statistical analysis that complement the process of detailing the dependence of the resulting and factor indicators under study.

Assessing the sustainability indicators of their business process management, organizations, using the selected methods will be able to receive up-to-date and scrupulous information about the influence of factor indicators on the resulting indicators in general and in particular (for individual constituent components of the business environment), which, in turn, affect result and costs (fundamental factors of efficiency and competitiveness, including management).

\section{Results and discussion}

For the formation of indicators, let us consider in more detail endogenous and exogenous factors of the environment for the functioning of business processes. Endogenous factors include internal strategy, production, product quality, human resources, internal investment, internal innovation, internal workflow and internal legal issues. Exogenous factors are subdivided into microenvironmental factors (strategy for working with clients and partners, 
sales, product sales quality, external investment, external innovation, external workflow, external legal issues) and macroenvironmental factors (external strategy for adapting to general changes in the basis and superstructure in national and international scale). Both groups of the environment for the functioning of business processes require from organizations the corresponding costs, consisting of the following groups of costs:

1. Endogenous management costs (costs in a controlled environment for the functioning of business processes caused by the costs of developing an internal strategy, conducting production, ensuring product quality, investing in real assets, maintenance, operation, execution of relevant documents and solving relevant legal issues).

2. Exogenous administrative costs at the micro level (costs in an uncontrolled direct environment of the functioning of business processes caused by the costs of interest from customers and partners, sales of products and their quality, investments in financial assets, execution of relevant documents and solution of relevant legal issues).

3. Exogenous administrative costs at the macro level (costs in an uncontrolled indirect environment of business processes caused by the costs of adapting to changes in national and international economic and legal relations).

Endogenous management costs determine opportunities and exogenous management costs - the limitations of organizations in resisting the current economic environment and together form their potential, which must be fully realized to achieve maximum managerial stability, manifested in the efficiency and cost of funds (sustainability efficiency) and their influence on changing the result and the costs of activities (sustainability intensification), pursuant to the considered structure of modern costs in a controlled and uncontrolled environment for the functioning of business processes.

Using these postulates, we will form efficiency indicators of the sustainability of management of organizations (formulas (1), (2), (3), (4)):

$$
\mathrm{PT}_{\text {уо(д) }}=\frac{\text { СДо }}{\mathrm{P}_{\text {оэн }}+\mathrm{P}_{\text {оэкп }}+\mathrm{P}_{\text {оэкк }}} \text {, }
$$

where $\mathrm{PT}_{\mathrm{yo}(д)}$ - total efficiency of the sustainability of the management of organizations in terms of income;

$\mathrm{CД}_{\mathrm{o}}$ - total income of organizations, RUR;

$\mathrm{P}_{\text {оэн }}$ - endogenous costs of organizations to ensure management sustainability, RUR; RUR;

$\mathrm{P}_{\text {оэкп }}$ - direct exogenous costs of organizations to ensure management sustainability, RUR;

$\mathrm{P}_{\text {оэкк }}$ - indirect exogenous costs of organizations to ensure management sustainability,

$$
\mathrm{PT}_{\text {уо(п) }}=\frac{\mathrm{C \Pi}_{\mathrm{o}}}{\mathrm{P}_{\text {оэн }}+\mathrm{P}_{\text {оэкп }}+\mathrm{P}_{\text {оэкк }}},
$$

where $\mathrm{PT}_{\mathrm{yo}(\mathrm{I})}$ - total efficiency of the sustainability of management of organizations in terms of profit;

$\mathrm{C}_{\mathrm{o}}$ - total profit of organizations, RUR;

$\mathrm{P}_{\text {оэн }}$ - endogenous costs of organizations to ensure management sustainability, RUR; RUR;

$\mathrm{P}_{\text {оэкп }}$ - direct exogenous costs of organizations to ensure management sustainability, RUR;

$\mathrm{P}_{\text {оэкк }}$ - indirect exogenous costs of organizations to ensure management sustainability,

$$
3 \mathrm{~T}_{\text {уо(д) }}=\frac{\mathrm{P}_{\text {оэн }}+\mathrm{P}_{\text {оэкп }}+\mathrm{P}_{\text {оэкк }}}{\text { СДо }_{0}},
$$

where $3 \mathrm{~T}_{\text {уодд) }}$ - total cost of the sustainability of managing organizations in terms of income; 
$\mathrm{P}_{\text {оэн }}$ - endogenous costs of organizations to ensure management sustainability, RUR; RUR;

$\mathrm{P}_{\text {оэкп }}$ - direct exogenous costs of organizations to ensure management sustainability, RUR;

$\mathrm{P}_{\text {оэк }}$ - indirect exogenous costs of organizations to ensure management sustainability,

СД - total income of organizations, RUR;

$$
3 \mathrm{~T}_{\text {уо(п) }}=\frac{\mathrm{P}_{\text {оэн }}+\mathrm{P}_{\text {оэкп }}+\mathrm{P}_{\text {оэкк }}}{\text { СП }},
$$

where $3 \mathrm{~T}_{\mathrm{yo}(\mathrm{n})}-$ the total cost of the sustainability of the management of organizations in terms of profit;

$\mathrm{P}_{\text {оэн }}$ - endogenous costs of organizations to ensure management sustainability, RUR; RUR;

$\mathrm{P}_{\text {оэкп }}$ - direct exogenous costs of organizations to ensure management sustainability,

$\mathrm{P}_{\text {оэкк }}$ - indirect exogenous costs of organizations to ensure management sustainability, RUR;

$\mathrm{C}_{\mathrm{o}}$ - total profit of organizations, RUR;

Now we will form indicators of sustainability intensification of management of organizations, focusing on their essence, meaning maximizing the result and minimizing costs in a qualitative way (formulas (5), (6), (7), (8))

$$
\Delta \mathrm{CД}_{\text {оуд })}=\left[\frac{\mathrm{CД}_{\text {о1 }}}{\mathrm{P}_{\text {оэн1 }}+\mathrm{P}_{\text {оэкп1 }}+\mathrm{P}_{\text {оэкк1 }}}-\frac{\mathrm{CД}_{\text {о0 }}}{\mathrm{P}_{\text {оэн } 0}+\mathrm{P}_{\text {оэкп } 0}+\mathrm{P}_{\text {оэкк0 }}}\right]\left(\mathrm{P}_{\text {оэн1 }}+\mathrm{P}_{\text {оэкп1 }}+\mathrm{P}_{\text {оэкк1 }}\right) \text {, }
$$

where $\Delta \mathrm{CД}_{\text {оуд) }}$ - change in total revenues due to changes in the total efficiency of the sustainability of the management of organizations in terms of income, RUR;

СД ${ }_{01}$ - reported total income of organizations, RUR; RUR;

$\mathrm{P}_{\text {оэн1 }}$ - reported endogenous costs of organizations to ensure management sustainability,

$\mathrm{P}_{\text {оэкп1 }}$ - reported direct exogenous costs of organizations to ensure management sustainability, RUR;

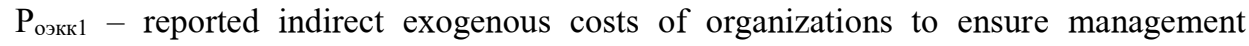
sustainability, RUR;

СД 0 - basic total income of organizations, RUR;

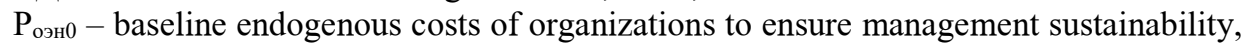
RUR;

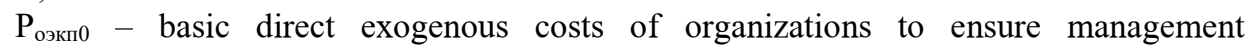
sustainability, RUR;

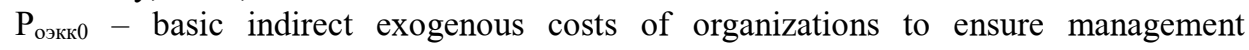
sustainability, RUR;

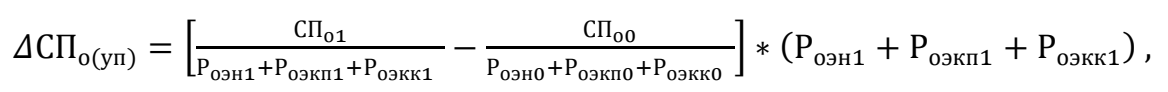

where $\Delta \mathrm{C} \Pi_{\text {оуп) }}$ - change in total profit due to changes in the aggregate efficiency of the sustainability of the management of organizations in terms of profit, RUR;

$\mathrm{C}_{\mathrm{ol}}$ - reported total profit of organizations, RUR;

$\mathrm{P}_{\text {оэн1 }}$ - reported endogenous costs of organizations to ensure management sustainability, RUR;

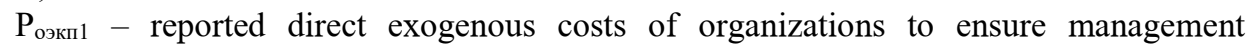
sustainability, RUR;

$\mathrm{P}_{\text {оэкк1 }}$ - reported indirect exogenous costs of organizations to ensure management sustainability, RUR;

$\mathrm{C} \Pi_{\mathrm{o} 0}$ - basic total profit of organizations, RUR; 
$\mathrm{P}_{\text {оэн } 0}$ - baseline endogenous costs of organizations to ensure management sustainability, RUR;

$\mathrm{P}_{\text {оэкпо - basic direct exogenous costs of organizations to ensure management }}$ sustainability, RUR;

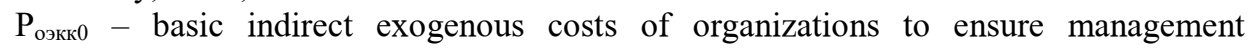
sustainability, RUR;

$$
\Delta \mathrm{CP}_{\text {оуд })}=\left[\frac{\mathrm{P}_{\text {оэн1 }}+\mathrm{P}_{\text {оэкп1 }}+\mathrm{P}_{\text {оэкк1 }}}{\mathrm{CДо1}}-\frac{\mathrm{P}_{\text {оэн } 0}+\mathrm{P}_{\text {оэкп } 0}+\mathrm{P}_{\text {оэкк0 }}}{\mathrm{CДо0}}\right] * \mathrm{CД}_{\mathrm{o} 1} \text {, }
$$

where $\Delta \mathrm{CP}_{\text {о(уд) }}$ - change in total costs due to changes in the total cost of stability of management of organizations in terms of income, RUR; RUR;

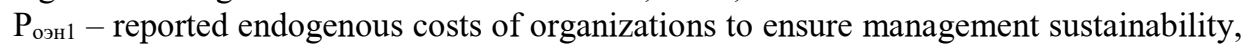

$\mathrm{P}_{\text {оэкп1 }}$ - reported direct exogenous costs of organizations to ensure management sustainability, RUR;

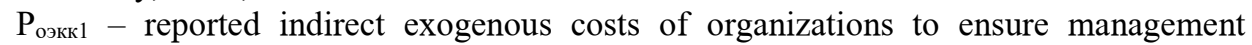
sustainability, RUR;

СД $Д_{\circ 1}$ - reported total income of organizations, RUR;

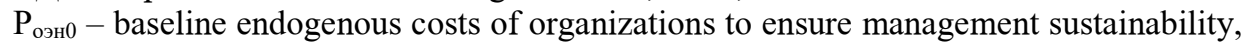
RUR;

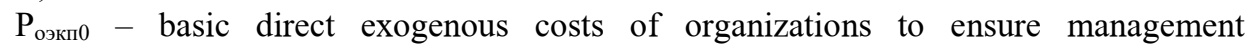
sustainability, RUR;

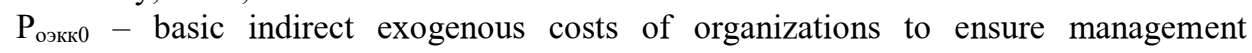
sustainability, RUR;

CД $Д_{0}$ - basic total income of organizations, RUR;

$$
\Delta \mathrm{CP}_{\text {оуп })}=\left[\frac{\mathrm{P}_{\text {оэн1 }}+\mathrm{P}_{\text {оэкп1 }}+\mathrm{P}_{\text {оэкк1 }}}{\mathrm{CПо1}}-\frac{\mathrm{P}_{\text {оэн } 0}+\mathrm{P}_{\text {оэкп } 0}+\mathrm{P}_{\text {оэкк0 }}}{\mathrm{C} П о 0}\right] * \mathrm{CП}_{\text {о1 }} \text {, }
$$

where $\Delta \mathrm{CP}_{\mathrm{o}(\mathrm{y}}$ - - change in total costs due to changes in the total cost of sustainability of management of organizations in terms of profit, RUR;

$\mathrm{P}_{\text {оэн1 }}$ - reported endogenous costs of organizations to ensure management sustainability, RUR;

$\mathrm{P}_{\text {оэкп1 - reported direct exogenous costs of organizations to ensure management }}$ sustainability, RUR;

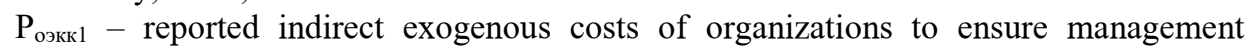
sustainability, RUR;

$\mathrm{C}_{\mathrm{ol}}$ - reported total profit of organizations, RUR; RUR;

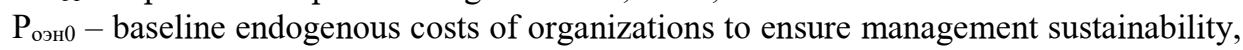

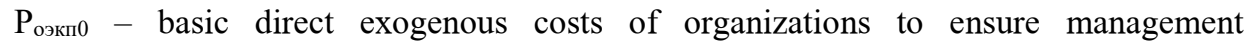
sustainability, RUR;

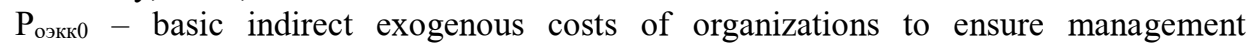
sustainability, RUR;

$\mathrm{C} \Pi_{\mathrm{o} 0}$ - basic total profit of organizations, RUR.

The indicators formed by the authors fully correspond to the concept of sustainability of management of organizations, since the efficiency (profitability and profitability) and cost (expenditure on income and profit) and change in the result (income and profit) and costs (expenses) fully reflect its essence and content. in relation to the modern conditions inherent in the current business environment.

Explanations of the indicators of management sustainability of organizations formed by the authors are presented in table 1,2 . 
Table 1. Interpretation of indicators of sustainability of management of organizations by income

\begin{tabular}{|l|l|}
\hline \multicolumn{1}{|c|}{ Indicator } & \multicolumn{1}{|c|}{ Contents } \\
\hline $\begin{array}{l}\text { Total performance of the sustainability } \\
\text { of the management of organizations in } \\
\text { terms of income }\end{array}$ & $\begin{array}{l}\text { The total revenues of organizations per unit of the amount } \\
\text { of their expenses in the endogenous, direct and indirect } \\
\text { exogenous environment to ensure management activities }\end{array}$ \\
\hline $\begin{array}{l}\text { Total cost of sustainability of } \\
\text { managing organizations in terms of } \\
\text { income }\end{array}$ & $\begin{array}{l}\text { The amount of expenses of organizations in an } \\
\text { endogenous, direct and indirect exogenous environment to } \\
\text { ensure management activities per unit of their total income }\end{array}$ \\
\hline $\begin{array}{l}\text { Change in total income due to changes } \\
\text { in the total performance of the } \\
\text { sustainability of management of } \\
\text { organizations in terms of income }\end{array}$ & $\begin{array}{l}\text { Increase (decrease) in the total income of organizations } \\
\text { due to an increase (decrease) in the result (total income) in } \\
\text { relation to the amount of their expenses in the endogenous, } \\
\text { direct and indirect exogenous environment to ensure } \\
\text { management activities }\end{array}$ \\
\hline $\begin{array}{l}\text { Change in total costs due to changes in } \\
\text { the total cost of stability of } \\
\text { management of organizations in terms } \\
\text { of income }\end{array}$ & $\begin{array}{l}\text { Saving (overexpenditure) of organizations' funds due to } \\
\text { their increase (decrease) in the amount of expenses in an } \\
\text { endogenous, direct and indirect exogenous environment to } \\
\text { ensure management activities to their result (total income) }\end{array}$ \\
\hline
\end{tabular}

Table 2. Interpretation of indicators of sustainability of management of organizations in terms of profit

\begin{tabular}{|l|l|}
\hline \multicolumn{1}{|c|}{ Indicator } & \multicolumn{1}{c|}{ Contents } \\
\hline $\begin{array}{l}\text { Total efficiency of the } \\
\text { sustainability of management of } \\
\text { organizations in terms of profit }\end{array}$ & $\begin{array}{l}\text { The total profit of organizations per unit of the amount of their } \\
\text { expenses in the endogenous, direct and indirect exogenous } \\
\text { environment to ensure management activities }\end{array}$ \\
\hline $\begin{array}{l}\text { The total cost of the sustainability } \\
\text { of the management of } \\
\text { organizations by profit }\end{array}$ & $\begin{array}{l}\text { The amount of expenses of organizations in an endogenous, } \\
\text { direct and indirect exogenous environment to ensure } \\
\text { management activities per unit of their total profit }\end{array}$ \\
\hline $\begin{array}{l}\text { Change in total profit due to } \\
\text { changes in the total efficiency of } \\
\text { the sustainability of the } \\
\text { management of organizations in } \\
\text { terms of profit }\end{array}$ & $\begin{array}{l}\text { Increase (decrease) in the total profit of organizations due to } \\
\text { an increase (decrease) in the result (total profit) in relation to } \\
\text { the amount of their expenses in the endogenous, direct and } \\
\text { indirect exogenous environment to ensure management } \\
\text { activities }\end{array}$ \\
\hline $\begin{array}{l}\text { Change in total costs due to } \\
\text { changes in the total cost of } \\
\text { sustainability of management of } \\
\text { organizations in terms of profit }\end{array}$ & $\begin{array}{l}\text { Saving (overexpenditure) of organizations' monetary funds } \\
\text { due to their increase (decrease) in the amount of expenses in } \\
\text { an endogenous, direct and indirect exogenous environment to } \\
\text { ensure management activities to their result (total profit) }\end{array}$ \\
\hline
\end{tabular}

They show the following advantages of the indicators of sustainability of management of organizations proposed by the authors:

1. Compliance with the modern environment elements for the functioning of business processes, consisting of endogenous and exogenous factors that affect the efficiency and intensification of managerial stability.

2. Assistance in accurate calculations of the levels of management performance and management costs and the degree of their impact on the result and management costs in dynamics and making timely decisions to achieve their best parameters.

Knowing about these advantages, organizations will receive objective information and use it to perform the required measures to optimize, including endogenous and exogenous management costs, thanks to which they will be able to derive maximum financial benefit and, accordingly, achieve full sustainability of their management.

\section{Conclusions}

The indicators of stability of management of organizations, proposed by the authors, are fully adapted to the conditions of the economic environment, since they correspond to the structure 
of the factors of the environment for the functioning of business processes of the modern era. They will become a significant tool for in obtaining total and scrupulous information about the efficiency and cost of funds to ensure overall managerial stability and endogenous and exogenous business conditions.

Generated indicators consist of a complete list of costs in the field of ensuring managerial stability, represented by the costs of organizations in a controlled and uncontrolled environment of their business processes, required to calculate the financial benefits from their management.

Thus, proposed indicators correspond to the prevailing realities in the environment of the functioning of business processes, they are consistent and applicable by organizations to assess their managerial stability in the modern environment, which means achieving goals and solving problems.

\section{References}

1. V. Andreyev, K. Pavlov, Society and economy, 6, 152 (2006)

2. N.S. Antonova, Sales management, 2, 136 (2016)

3. A.S. Belanovsky, Sales management, 1, 34 (2017)

4. S.N. Efimushkin, A.S. Krasnikova, Creative economy, 12(96), 63 (2014)

5. A.M. Zhemchugov, M.K. Zhemchugov, Management today, 3, 196 (2017)

6. M.A. Kovtun, G.S. Isaakov, Economy today: current state and prospects of development, 180 (2017)

7. I. Kurnysheva, S. Lykov, A. Idrisov, Economist, 9, 39 (2008)

8. K.V. Pavlov, S.N. Rastvortseva, National interests: priorities and safety, 4(25), 28 (2008)

9. V.A. Rogova, Russian technological magazine, 6(4), 105 (2008)

10. R.O. Suleymanov, Information security of regions, 2(15), 72 (2014)

11. B.N. Khosiyev, G.Ya. Ostayev, Z.T. Kokoyeva, Accounting in agriculture, 5, 39 (2018) 